\title{
First record of the endoparasitic isopod Portunion maenadis (Giard, 1886) (Epicaridea: Entoniscidae) in shore crabs in the Wadden Sea and a review of its distribution in Europe
}

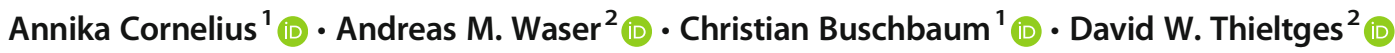 \\ Received: 1 July 2019 /Revised: 29 August 2019 / Accepted: 5 September 2019/Published online: 19 November 2019 \\ (C) The Author(s) 2019
}

\begin{abstract}
The knowledge on the distribution and abundance of marine parasites is still limited, even for those occurring on relatively well studied host species with high ecological importance. Here we report on the first record of the entoniscid Portunion maenadis (Giard, 1886) in European shore crabs (Carcinus maenas L., 1758) in the Wadden Sea and provide a quantitative review of the parasite's distribution in Europe based on published literature and biodiversity database records. Our new record closes a distribution gap of $P$. maenadis between previous southern observations in Portugal and France and northern occurrences in Denmark and Sweden. The additional literature survey suggests that $P$. maenadis is not very common and only occurs at scattered localities with prevalence of infestations usually well below $10 \%$ in host crab populations. However, the $45 \%$ prevalence observed in our study in November 2018 in the southern Wadden Sea indicates that also higher prevalences can occur. As the adult parasites feed on their host's hemolymph they are likely to have consequences for the host's energy budgets. In addition, infestations lead to morphological changes in the form of feminisation of male crabs (i.e. broader pleon, slender claws, bulging carapace) which we observed in several individuals. With this new record and literature review, we hope to spark future research into the distribution of this intriguing parasite species as well as on the impacts of infestations on shore crab hosts.
\end{abstract}

Keywords Biogeography $\cdot$ Carcinus maenas $\cdot$ Parasitism

\section{Introduction}

Although parasites are ubiquitous in marine ecosystems our knowledge on their distribution and biology is still limited (Poulin et al. 2016). This compromises a full appreciation of the biodiversity in the marine realm and also hampers our understanding of the ecological relevance of parasites in marine ecosystems as they are known to often cause an array of

Communicated by S. Kaiser

Electronic supplementary material The online version of this article (https://doi.org/10.1007/s12526-019-01012-3) contains supplementary material, which is available to authorized users.

David W. Thieltges

David.Thieltges@nioz.nl

1 Alfred-Wegener-Institut Helmholtz-Zentrum für Polar- und Meeresforschung, Wattenmeerstation Sylt, Hafenstr. 43, 25992 List, Germany

2 Department of Coastal Systems, NIOZ Royal Netherlands Institute for Sea Research and Utrecht University, Den Burg, The Netherlands direct and indirect effects on host individuals, populations and communities (Lafferty and Harvell 2014; Thieltges et al. 2018). Knowledge on the geographical distribution of marine parasites and infestation levels in their hosts is thus an important first step into understanding the ecological role of marine parasitism. However, for most marine species their parasite fauna is poorly known and even for the better-studied host species knowledge on rare parasite species is often very limited. This applies to parasites of the shore crab Carcinus maenas L., 1758 which is native to European shores, where the predatory crab frequently has an important role in regulating the population dynamics of a variety of prey species (Beukema and Dekker 2014). The European shore crab has attracted considerable parasitological attention as it is invasive in other parts of the world and a release from its native parasites has been suggested as an explanation for its invasion success (enemy or parasite release hypothesis; Torchin et al. 2003). The general parasite fauna of C. maenas is well known and includes at least 10 species with trematodes, acanthocephalans and rhizocephalans being the common parasite groups in respect to distribution and infestation levels (Torchin et al. 
2001; Blakeslee et al. 2009). However, for less common parasites, geographical distributions and infestation levels are not well known.

Here we report on the first record of the entoniscid (Crustacea, Isopoda) Portunion maenadis (Giard, 1886) in shore crabs (C. maenas) in the Wadden Sea and provide a review on the parasite's distribution in Europe based on published literature and biodiversity database records. With our data, we aim to complement knowledge on the distribution of marine parasites occurring at coastal areas in Europe and to encourage future research into the distribution, biology and effects of marine parasite species, which are still understudied in marine biodiversity and community ecology research.

\section{Materials and methods}

During a recent parasite monitoring, we sampled adult shore crabs (C. maenas) in the northern Wadden Sea around the island of Sylt and in the southern Wadden Sea around the island of Texel (Fig. 1) between autumn 2018 and spring 2019. At both locations, adult crabs (males and females, carapace width $\geq 20 \mathrm{~mm}$ ) were hand-collected in the intertidal at the bottom of dykes or on mixed reefs of native blue mussel (Mytilus edulis L., 1758) and introduced Pacific oysters (Magallana gigas Thunberg, 1793). On Sylt, we sampled on a mixed bed in the north of the island ( $n=18$ and 10 for 2018 and 2019, respectively) and a mixed bed at the south of the island ( $n=2$ for 2019). On Texel, we sampled at a mixed bed in the north $(n=25$ for 2019) and a mixed bed with an adjacent dyke in the south ( $n=11$ and 40 for 2018 and 2019, respectively). In the laboratory, the crabs were euthanised by briefly freezing them at $-18{ }^{\circ} \mathrm{C}$ before dissections on the same day. For each crab, the carapace width was measured with a calliper and the sex determined and potential signs of morphological feminisation in male crabs, such as widened pleon, were noted. The carapace of each crab was carefully removed after cutting along the suture with a scalpel. The presence or absence of adult females of Portunion maenadis in crabs was noted and the prevalence ( $\%$ of crabs infested at a location) for each site on both islands was calculated. Additionally, we plotted the size-frequency distribution of infested and noninfested crabs and compared infestation levels in males and females using a Chi-square test.

In addition to the field sampling and dissections, we conducted a literature search on published records of $P$. maenadis using academic literature search engines (Google Scholar, Web of Science) and browsed the reference sections of publications for further references. We also searched for general parasitological studies of shore crabs (C. maenas) in Europe in the same manner. In addition, we searched for records in biodiversity databases and museum collections (World Register of Marine Species (WoRMS), obis.org, GBIF.org).
For all publications and records we obtained with our search, we recorded the location name and the latitude and longitude either from the original sources or from maps. In addition, we recorded the sampling year and season and the number of dissected crabs as well as the number of infested crabs if this information was available from the source. We plotted all $P$. maenadis records on a map and also added locations where shore crabs had been investigated for parasites but where $P$. maenadis was not found. Finally, we calculated infestation prevalence for those locations where quantitative data (sampling effort and number of infested crabs) were available.

\section{Results}

During our sampling of 106 shore crabs between autumn 2018 and spring 2019 we recorded adult females of P. maenadis (Fig. 2a, b) in the northern and southern Wadden Sea at one of the two sites on the islands of Sylt and Texel, respectively (Fig. 1). On Sylt, P. maenadis was only recorded at the southern location in spring 2019 (prevalence 50\%, however, with only two crabs sample size was very low) while on Texel it was recorded at the southern location during both sampling periods with lower prevalence during the second sampling event (autumn 2018 45.5\%, 5 out of 11 crabs; spring 2019 $15 \% ; 6$ out of 40 crabs; overall $21.6 \%$ ). The overall infestation levels with P. maenadis for Sylt and Texel were 3.3\% $(n=30)$ and $14.5 \%(n=76)$, respectively. Infested crabs had a carapace width between 27 and $57 \mathrm{~mm}$ (size range sampled 20 $65 \mathrm{~mm}$ ) and males (prevalence 14.7\%) tended to be more infested than females (7.7\%), however, this difference was not statically significant (chi-square test; $p=0.41$; Online Resource 2). In all infested $C$. maenas, we never detected more than a single adult female Portunion maenadis. Ovigerous female parasites were found in autumn and spring, carrying epicaridium larvae (Fig. 2d). Male $C$. maenas with $P$. maenadis generally showed signs of feminisation (broadened pleon, slender claws and bulging carapace; Fig. 2c). For raw data see Cornelius et al. (2019).

The literature search resulted in 82 additional locations throughout Europe where P. maenadis was either recorded in $C$. maenas or where crabs were screened for parasites but the parasite not found (Fig. 1; for full list and details on locations see Online Resource 1). Overall, the parasite was detected at 26 locations (Fig. 1), from which 16 locations were quantitatively investigated for $P$. maenadis infestation (Table 1). The most northern record was at Kristineberg in Sweden and the most southern observation at Mira River in Portugal. Prevalence at these locations was generally below $10 \%$ in the investigated crabs, apart from one observation at Arcachon in France (15.3\%; Table 1 and Online Resource 1) and, thus, lower than in our study. 
Fig. 1 Locations in Europe where the entoniscid Portunion maenadis has been recorded (orange circles) in shore crabs (Carcinus maenas) and locations where shore crabs had been investigated for parasite infestations but where no P. maenadis were found (blue circles). The inserts show the two sampling sites of our study (orange quadrats) in the northern (Sylt) and southern (Texel) Wadden Sea. The pie charts in the inserts show infestation prevalence of adult crabs, and white numbers inside the pies indicate the sample size. For sources and details, see Online Resource 1

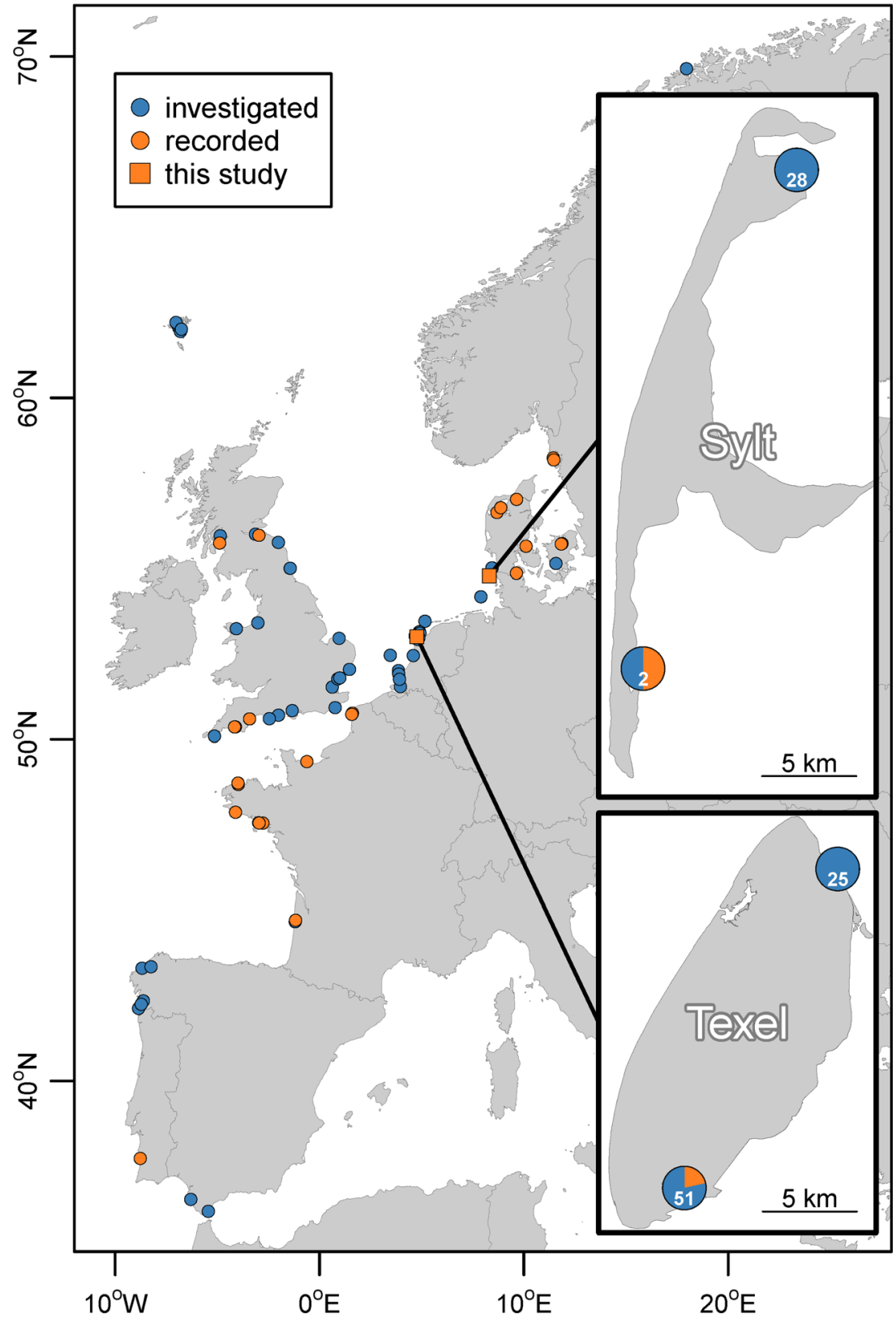

\section{Discussion}

Our records of shore crabs (C. maenas) infested with adult females of $P$. maenadis at two locations in the Wadden Sea close a distribution gap of this entoniscid species between previous southern observations in Portugal and France and northern occurrences from Denmark and Sweden. It is the first record for the Wadden Sea region and the second record for the North Sea as a whole aside from a specimen from the Firth of Forth in Scotland which stems from a private collection from approximately 1920/1930 which was integrated into the collection of the Natural History Museum London in 1958 (Natural History Museum 2019). Since then, there have been several parasitological studies on shore crabs
(C. maenas) in the North Sea area, none of which observed P. maenadis (Goudswaard 1985; Stentiford and Feist 2005; Thieltges et al. 2008; Blakeslee et al. 2009; Zetlmeisl et al. 2011; Goedknegt et al. 2017; Bojko et al. 2018). This indicates that the parasite is relatively rare and has a very patchy distribution on a regional scale. This also seems to be true on a local scale as we only found $P$. maenadis at one of the two locations sampled on each island; however, we acknowledge that the sample size in our survey was relatively small. At locations where $P$. maenadis is generally present, it is not very common in crab hosts and prevalence is usually well below $10 \%$ in the adult crab population as indicated from our literature survey. However, in some cases, higher prevalence has been observed (Table 1) and, in particular, our observation of a 
Fig. 2 a Shore crab (Carcinus maenas) infested with the entoniscid Portunion maenadis (arrow); $\mathbf{b}$ individual adult female parasite (approx. $3 \mathrm{~cm}$ length; arrow) removed from its host (top); c infested male shore crab showing signs of feminisation (broadened pleon; arrow); and d epicaridium larval stages of the parasite removed from the marsupium (scale bar $500 \mu \mathrm{m}$ ). Photo copyrights: a, c, d: Annika Cornelius, b: Judith Hermann

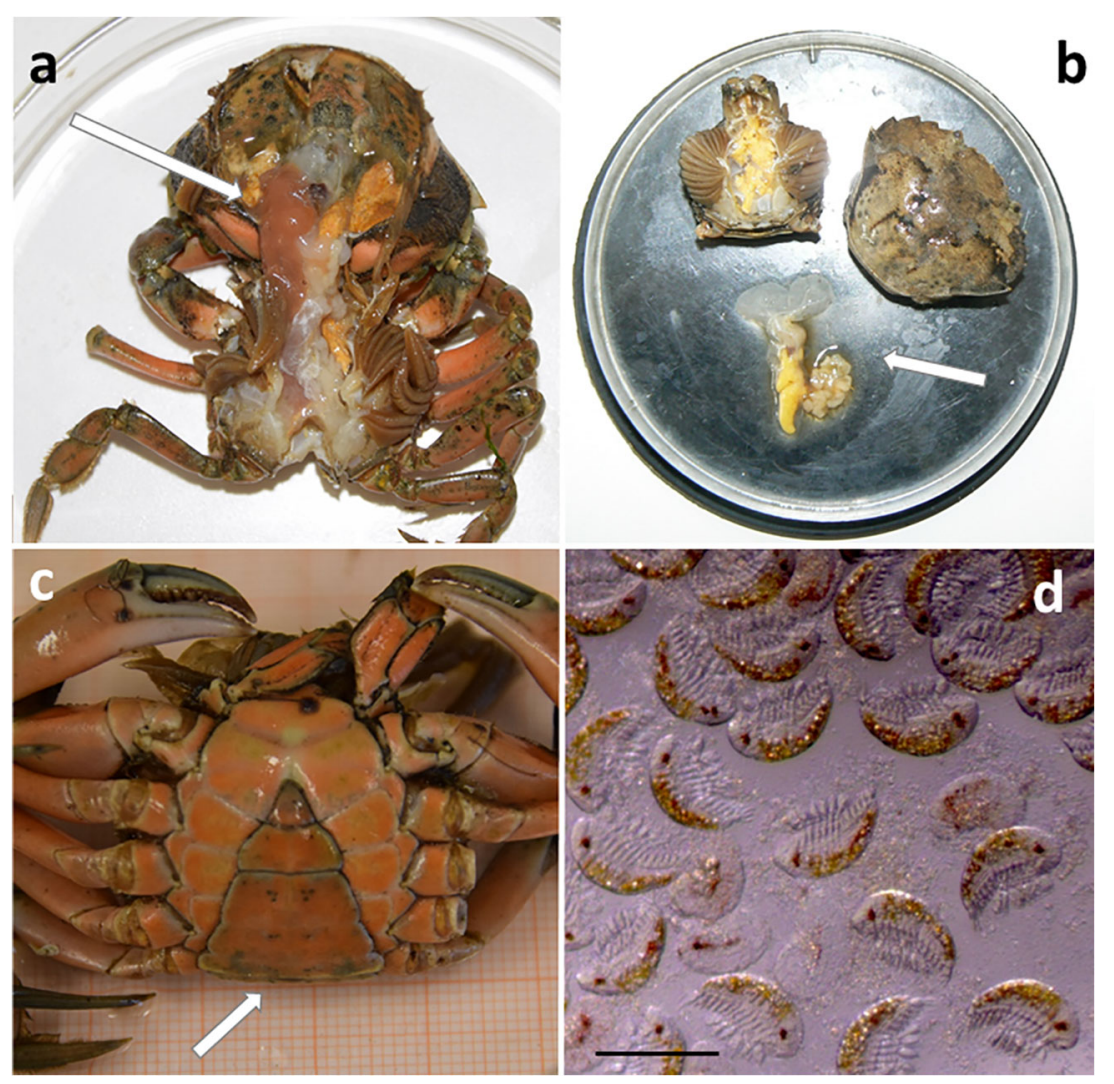

Table 1 Prevalence of the entoniscid Portunion maenadis in shore crabs (Carcinus maenas) from different locations in Europe for which quantitative data were available

\begin{tabular}{llllll}
\hline Location & Country & $\begin{array}{l}\text { Prevalence } \\
(\%)\end{array}$ & $\begin{array}{l}\text { Sampling } \\
\text { year }\end{array}$ & $\begin{array}{l}\text { Sampling } \\
\text { effort }\end{array}$ & Source \\
\hline Kristineberg & Sweden & 4.8 & 2000 & 21 & Blakeslee et al. 2009 \\
Ellös & Sweden & 2.3 & 1996 & 348 & Høeg et al. 1997 \\
Kattegat & Denmark & 1.5 & 2005 & 67 & Zetlmeisl et al. 2011 \\
Kattegat & Denmark & 6.4 & 2008 & 109 & Zetlmeisl et al. 2011 \\
Isefjord & Denmark & 3 & $1960-1962$ & 1710 & Rasmussen 1973 \\
Isefjord & Denmark & 1.6 & 1960 & 63 & Rasmussen 1973 \\
Limfjorden & Denmark & 2.3 & 2006 & 129 & Zetlmeisl et al. 2011 \\
Limfjorden & Denmark & 2.5 & 2007 & 240 & Zetlmeisl et al. 2011 \\
Limfjorden & Denmark & 4.3 & 2006 & 115 & Zetlmeisl et al. 2011 \\
Sylt & Germany & 3.3 & $2018-2019$ & 30 & This study \\
Texel & Netherlands & 14.5 & $2018-2019$ & 76 & This study \\
Firth of Clyde & UK & 0.6 & 1993 & 639 & Searle and Crompton \\
Exmouth & UK & 0.2 & 1924 & 661 & 1995 \\
Plymouth & UK & 0.4 & 1923 & 250 & Perkins 1924 \\
Plymouth & UK & 10 & 2000 & 20 & BBA 1957 \\
Saint-Pol-de-Léon & France & 4.5 & 2000 & 22 & Blakeslee et al. 2009 \\
Bassin & France & 15.3 & 1964 & 550 & Bourdon 1964 \\
$\begin{array}{l}\text { d'Arcachon } \\
\text { Mira River }\end{array}$ & Portugal & 3.2 & 2000 & 62 & Blakeslee et al. 2009 \\
\hline & & & & & \\
\hline
\end{tabular}

Given are also the sampling year and effort (number of crabs dissected) at the different locations 
prevalence of $45 \%$ in adult crabs sampled in November 2018 at Texel in the southern Wadden Sea seems to be unique. The prevalence (50\%) at the southern location of Sylt needs to be interpreted with caution, since only two adult individuals were investigated for the parasite infestation.

Why the occurrence of $P$. maenadis is so patchy and why prevalence differs among locations is not known and we can only offer speculation. Some of the patterns observed may result from the life cycle of the parasite which involves two sequential hosts (for more details see Veillet 1945, Williams and Boyko 2012). From the eggs of P. maenadis, epicaridium larval stages hatch and infest calanoid copepods (intermediate host). The larvae settle on the outer body wall of the copepods and metamorphose into a microniscus stage that lives ectoparasitically and feeds on the host's haemolymph. At some point, the microniscus larvae abandon the copepod host and turn into free-living cryptoniscus larvae that intrude into the abdominal cavity of shore crabs (definitive host). Here females metamorphose into a sack-like structure (Fig. 2b) and grow by feeding on the hemolymph in the hemocoel to about $4 \mathrm{~cm}$ length while males turn into a sexually mature form of only $1-3 \mathrm{~mm}$ in length. This life cycle makes it necessary that all suitable hosts are locally present and that males and females occur together in infected crabs and it seems reasonable to assume that this results in the patchy distribution and the low prevalence generally observed in P. maenadis. The observed drop in prevalence from November 2018 to April 2019 at Texel could relate to seasonal patterns of infestation but whether such patterns exist is difficult to tell as only observations from summer are available from the literature (see Online Resource 1).

Alternatively, the drop in infestation levels between our sampling events may indicate a negative effect of P. maenadis on crab fitness. As adult parasites feed on their hosts' haemolymph they are likely to have consequences for the hosts' energy budgets. Such an energy burden is generally observed in hosts of epicaridean parasites and assumed to ultimately lead to castration of the host (O'Brien and Van Wyk 1985). The energy drain caused by the parasites may be particularly deleterious in the winter months when food is scarce and may elevate mortality of infected crabs, leading to the observed drop in prevalence in spring. However, experimental studies would be needed to investigate whether this speculative mechanism actually exists. In addition to potential energetic effects, infestations with $P$. maenadis may also lead to morphological changes in the form of feminisation of male crabs (i.e. broader pleon, slender claws, bulging carapace; Rasmussen 1973). This was also observed in our samples from the Wadden Sea (Fig. 2c). Whether there are also behavioural and distributional changes associated with infestations such as the ones observed in infestations with the rhizocephalan Sacculina carcini Thompson, 1836, which makes male and female crabs behave like egg-bearing females, moving into deeper waters (Waser et al. 2016), is unclear and remains to be studied. We hope that the results of our sampling of $P$. maenadis in the Wadden Sea and the additional literature review on its European distribution will stimulate future research into the occurrence of this intriguing parasite species as well as on the impacts of parasite infestations on host populations and community ecology in general, because the role of parasitism in shaping communities may be of equal importance as other biotic factors such as predation and competition (Thieltges et al. 2018).

Acknowledgements We thank Judith Hermann for allowing us to use her photo.

Funding information This study was funded by the German Environmental Foundation (DBU), grant no. 20018/530.

\section{Compliance with ethical standards}

Conflict of interest The authors declare that they have no conflict of interest.

Ethical approval All applicable international, national, and institutional guidelines for animal testing, animal care and use of animals were followed by the authors.

Sampling and field studies All necessary permits for sampling and observational field studies have been obtained by the authors from the competent authorities. The study is compliant with CBD and Nagoya protocols.

Data availability All data generated or analysed during this study are included in this published article and its supplementary information files and in a public repository (4tu.nl).

Open Access This article is distributed under the terms of the Creative Commons Attribution 4.0 International License (http:// creativecommons.org/licenses/by/4.0/), which permits unrestricted use, distribution, and reproduction in any medium, provided you give appropriate credit to the original author(s) and the source, provide a link to the Creative Commons license, and indicate if changes were made.

\section{References}

Beukema J, Dekker R (2014) Variability in predator abundance links winter temperatures and bivalve recruitment: correlative evidence from long-term data in a tidal flat. Mar Ecol Prog Ser 513:1-15. https://doi.org/10.3354/meps10978

Blakeslee AMH, Keogh CL, Byers JE et al (2009) Differential escape from parasites by two competing introduced crabs. Mar Ecol Prog Ser 393:83-96. https://doi.org/10.3354/meps08225

Bojko J, Stebbing P, Dunn A et al (2018) Green crab Carcinus maenas symbiont profiles along a North Atlantic invasion route. Dis Aquat Org 128:147-168. https://doi.org/10.3354/dao03216

Bourdon R (1964) Épicarides et rhizocéphales du Bassin d'Arcachon. Proces Verbaux Soc Linn Bordeaux 101:1-7 
Cornelius A, Waser AM, Buschbaum C et al. (2019) First record of the endoparasitic isopod Portunion maenadis (Giard, 1886) (Epicaridea: Entoniscidae) in shore crabs in the Wadden Sea and a review of its distribution in Europe. NIOZ Royal Netherlands Institute for Sea Research. Data set. https://doi.org/10.4121/uuid: 01615503-fc4f-4a6c-b91a-19bdd425743a

Goedknegt MA, Havermans J, Waser AM et al (2017) Cross-species comparison of parasite richness, prevalence, and intensity in a native compared to two invasive brachyuran crabs. Aquat Invasions 12: 201-212. https://doi.org/10.3391/ai.2017.12.2.08

Goudswaard PC (1985) Onderzoek naar het voorkomen van Portunion maenadis en Priapion fraissei (Isopoda: Epicaridea) in het Nederlandse kustgebied. Zool Bijdr 32:1-15

Høeg J, Glenner H, Werner M (1997) The epicaridean parasite Portunion moenadis as a biological control agent on Carcinus maneas. In: Thresher RE (ed) Proceedings of the first international workshop on the demography, impacts and management of the introduced populations of the European crab, Carcinus maenas. CSIRO Marine Laboratories, Hobart, pp 85-86

Lafferty KD, Harvell CD (2014) The role of infectious diseases in marine communities. In: Bertness MD, Bruno JF, Silliman BR, Stachowicz JJ (eds) Marine community ecology and conservation. Sinauer Associates Incorporated, Sunderland, pp 85-108

MBA (Marine Biological Association) (1957) Plymouth marine fauna, 3rd edn. Marine Biological Association of the United Kingdom, Plymouth

Natural History Museum (2019). Natural History Museum (London) Collection Specimens. Occurrence dataset. https://doi.org/10.5519/ 0002965 accessed via GBIF.org on 2019-05-23. https://www.gbif. org/occurrence/1056819633

O’Brien JJ, Van Wyk P (1985) Effects of crustacean parasitic castrators (Epicaridean isopods and rhizocephalan barnacles) on growth of crustacean hosts. In: Wenner AM (ed) crustacean issues: factors in adult growth. A.A. Balkema, Rotterdam, pp 191-218

Perkins M (1924) Two abnormal chelae of Carcinus maenas, pennant. Ann Mag Nat Hist 14:136-138. https://doi.org/10.1080/ 00222932408633098

Poulin R, Blasco-Costa I, Randhawa HS (2016) Integrating parasitology and marine ecology: seven challenges towards greater synergy. J Sea Res 113:3-10. https://doi.org/10.1016/j.seares.2014.10.019

Rasmussen E (1973) Systematics and ecology of the Isefjord marine fauna (Denmark). Ophelia 11:1-507. https://doi.org/10.1080/ 00785326.1973 .10430115
Searle DW, Crompton DWT (1995) Observations on Portunion maenadis (Isopoda, Epicaridea, Entoniscidae), parasitic in Carcinus maenas (Decapoda, Reptantia, Portunidae) from the firth of Clyde, Scotland. Crustaceana 68:403-405. https://doi.org/10. 1163/156854095X01538

Stentiford GD, Feist SW (2005) A histopathological survey of shore crab (Carcinus maenas) and brown shrimp (Crangon crangon) from six estuaries in the United Kingdom. J Invertebr Pathol 88:136-146. https://doi.org/10.1016/j.jip.2005.01.006

Thieltges DW, Hussel B, Hermann J et al (2008) Parasites in the northern Wadden Sea: a conservative ecosystem component over 4 decades. Helgol Mar Res 62:37-47. https://doi.org/10.1007/s10152-0070091-6

Thieltges DW, Mouritsen KN, Poulin R (2018) Ecology of parasites in mudflat ecosystems. In: Beninger PG (ed) Mudflat ecology. Springer International Publishing, Cham, pp 213-242

Torchin ME, Lafferty KD, Dobson AP et al (2003) Introduced species and their missing parasites. Nature 421:628-630. https://doi.org/10. 1038/nature 01346

Torchin ME, Lafferty KD, Kuris AM (2001) Release from parasites as natural enemies: increased performance of a globally introduced marine crab. Biol Invasions 3:333-345. https://doi.org/10.1023/A: 1015855019360

Veillet A (1945) Recherches sur le Parasitisme des Crabes et des Galathées par les Rhizocéphales et les Epicarides. Ann Inst Oceanogr 22:193-341

Waser AM, Goedknegt MA, Dekker R et al (2016) Tidal elevation and parasitism: patterns of infection by the rhizocephalan parasite Sacculina carcini in shore crabs Carcinus maenas. Mar Ecol Prog Ser 545:215-225. https://doi.org/10.3354/meps11594

Williams JD, Boyko CB (2012) The global diversity of parasitic isopods associated with crustacean hosts (Isopoda: Bopyroidea and Cryptoniscoidea). PLoS One 7:e35350. https://doi.org/10.1371/ journal.pone. 0035350

Zetlmeisl C, Hermann J, Petney T et al (2011) Parasites of the shore crab Carcinus maenas (L.): implications for reproductive potential and invasion success. Parasitology 138:394-401. https://doi.org/10. $1017 / \mathrm{S} 0031182010001344$

Publisher's note Springer Nature remains neutral with regard to jurisdictional claims in published maps and institutional affiliations. 